\title{
BUSINESS-GOVERNMENT INTERACTION: \\ A THEMATIC ANALYSIS
}

\author{
Oleg $\operatorname{Roy}^{1}$
}

date of paper receipt:

01.10.2019.

Original Article date of sending to review:

03.10.2019.

doi: 10.2478/eoik-2019-0018 date of review receipt:

11.10.2019.

UDK: 005.584.1:334.72.021(47)

${ }^{1}$ Omsk State University, Faculty of Economics, Russia

\begin{abstract}
The article analyzes the interaction between business and government, the purpose of which is to identify the leading thematic blocks, where the most significant issues underlying this interaction are concentrated. Highlighting two meanings in the practice of interaction between business and the state, in one of which the state merges with business, and in the other - disagrees with it on key issues, the author proposes to use the theory of stakeholders of I. M. Jawahar and G. L. McLaughlin. The use of this theory allows to identify several types of interaction, including six main functions: facilitating, stimulating, control, sanctions, arbitration and regulatory. The content of these functions is concentrated in the list of basic activities of authorities in the field of regulation of business processes. For the purpose of complex and systematic consideration of these functions, the article proposes a 3D model of interaction between government and business. On the basis of this model the author carries out the content analysis of materials of the leading among businessmen of the Omsk region newspaper "Commercial news" on the basis of which the leading thematic blocks of interaction of the power and business updated by various types of lighting are allocated (analytical article, interview, reportage, a note). The important role of the media in assessing and structuring the relationship between public authorities and business structures determines the usefulness content analysis and the choice of the object of the study. The study highlighted a number of leading thematic blocks of interaction, updated on the pages of the weekly in the period from 2018 to mid-2019. Based on the study, the author identified and ranked thematic blocks considered in the context of his proposed 3D- model, formulated the most characteristic problems of interaction between business and government at the present stage.
\end{abstract}

\section{Keywords:}

Business, government, stakeholder theory, content analysis, media, social interaction, small business, publication theme, institutional sustainability 


\section{INTRODUCTION}

The problem of interaction between business and government is one of the most relevant and developed in social science. The problematic nature of this interaction is manifested in the lack of trust among the parties and the fuzziness of the basis for the consolidation of their interests. Each side of the interaction relies on socially sanctioned institutions, developing its own strategy of behavior. Historically, the interaction of government and business can take different forms, the quality that is assessed by individual indicators of the economic condition of the society where this interaction takes place. However, by what indicators can be identify a particular form of interaction, the use of which empirical base will allow to form an adequate idea of the nature of the relationship between business and government? At present, the questions of how compatible the interests of business and government and in what areas it is possible to achieve maximum consolidation of their interests are becoming extremely relevant for the Russian economy? Answers to these questions will help to identify critical points in the interaction between business and government and develop possible options for optimizing these relations.

\section{THEORETICAL ANALYSIS OF THE PROBLEM}

The analysis of scientific sources testifies to rather deep differences existing in positions of business and the government. On the one hand, the importance of merging business and government, which causes deterioration of the business climate and contributes to corruption risks, is negatively assessed [1,2]. On the other hand, there is a deep divergence of interests between business and government, caused by the growing distrust of the parties to each other [3]. In Russian science, research interest is mainly aimed at highlighting several issues of interaction between business and government:

The problem of authority criminalizing, lobbying for the interests of some companies in government [4];

Building of partnerships between business and government, overcoming administrative barriers to business development [5];

Development of public-private partnership mechanisms [6];

The interaction of business and government in solving new urgent problems (the development of the Arctic, the transition to digital technology, etc.) [7];

Improving communication interaction (awareness of organizations on the issues of legislative regulation, development of consulting services, etc.), creation of business incubators [8,9].

Thus, we can state a wide variety of manifestations of interaction between government and business - from positive to negative results.

A good methodological basis for the study of the interaction of business and government can be the theory of stakeholders of I. M. Jawahar and G. L. McLaughlin [10]. According to this theory, by interacting with each other, the authorities and the business community develop a certain line of behavior that allows them to adequately distribute efforts depending on the position of the counterparty and the intentions expressed by him. The theory focuses on the typical nature of strategic decisions in interaction with counterparties (shareholders, investors, customers, governments, etc.), manifested in a certain set of rules determined by the nature of such interaction. The main types of interaction are:

- proactive - aimed at showing attention to the problems of stakeholders;

- adaptations - characterized by consideration of stakeholder problems, but not strictly mandatory response to them;

- protection-providing for the use of a minimum of actions in building relationships with stakeholders;

- reaction-consisting either of fighting against solutions to the problems of stakeholders, or their complete disregard. 
By interacting with each other, authorities and business structures solve certain tasks for themselves, which can be represented in the form of functions of such interaction. In our opinion, the main functions of interaction are: facilitating, stimulating, control, sanctions, arbitration and regulatory. All presented functions can be represented in the plane of three main axes, two of which reflect the two fundamental modes of public administration - "laissez faire (night watchman)" and "public Manager". The third axis is designed to ensure harmonization and synchronization of the actions of government in the implementation of the main functions. The first two functions are generally positive for business, while the other two are negative. Being the dominant of interaction, which determines the rules of this interaction, the government forces business to bear additional founding costs, allowing the entrepreneurial structure to become a party to this interaction. After all, being turned off from this interaction, the business unit loses a large list of opportunities, giving it the opportunity to realize all its abilities. with the assistance of the third pair - arbitration and regulatory functions - the government seeks to balance the interests of society and business, developing a list of direct and indirect ways to solve local problems and contentious situations.

Thus, the axis of development involves the facilitative and stimulative functions ("mode public administrator"), the axis of institutional stability - control and sanctions (mode "night watchman"), and the axis of operation - arbitration and governance.

Based on the theoretical reconstruction of the problem, a 3D model can be built . It based on the connection of the three main axes of interaction discussed above: institutional stability, operation and development (Fig. 1).

Figure 1. The structure of the model of interaction between business and government (3D-Model)

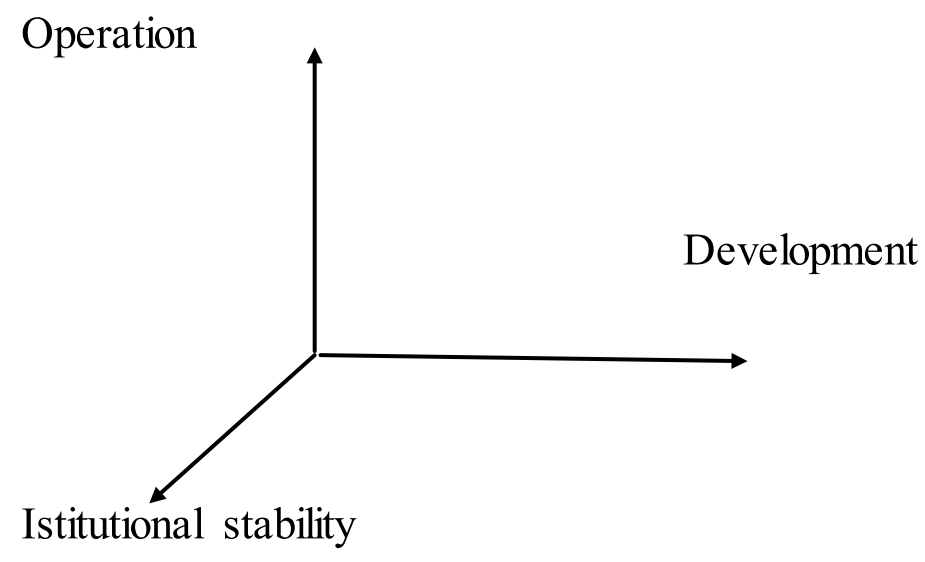

\section{ISTITUTIONAL STABILITY}

As practice shows, the manifestation of a particular function depends on the type of enterprise, its location, industry affiliation, as well as its age, i.e. position on the life cycle curve. Younger organizations are more likely to seek the inclinations of the government than established companies. Therefore, the question arose: on what thematic blocks there is a consolidation of interests of the government and business, and on what - no? The identification of such thematic blocks will improve the economic policy of the government, focusing it on solving the most pressing problems. Unfortunately, the relationship between the government and the corporate sector in Russia is not symmetrical. The government's interest in the corporate sector is embodied mainly in the use of its tax proceeds and the transfer of a number of social obligations to its shoulders. As a result, according to Rosstat, in 2018, 290288 enterprises were opened in Russia, while during the same period, 622111 companies ceased their activities. That is, the number of enterprises closed for the year exceeded the number of those opened by 2.14 times. At the end of the year, only in five regions of the Russian Federation, the number of newly created enterprises exceeded the number 
of closed ones. The main causes of death of enterprises experts call the high credit rate, limiting access to financial resources, lack of necessary business skills, personnel shortages, difficult access to markets and even lack of information about the support measures that offer a particular region [11].

Therefore, the attitude of the corporate sector to the government is embodied mainly in the desire to avoid its influence, to minimize their the tax and administrative costs. Especially difficult is the attitude of business to public policy in small enterprises the development of which is quite sensitive to changes in government policy in the economic sphere. Small businesses receive from the state not only a tax burden, but also help in solving their problems.

There are different ways to support the corporate sector in different countries, but the most common form is government support for small businesses. Small business is antimonopoly by nature, and with a narrow specialization and the use of the latest technology, small business can become a serious competitor to large corporations. This quality of small business has played a significant role in weakening and overcoming the tendency of industrialized countries to monopolize large capital and delay technological progress.

In some countries, the share of products produced by small enterprises reaches $80-90 \%$. In order to stimulate their activities and increase their role in the economy, the authorities determine a set of incentives measures for the appropriate types of enterprises. So in the United States significantly increased the threshold number of employees of small and medium-sized enterprises, which include firms with the number of employees up to 500 people in manufacturing, in wholesale trade up to 100 people in retail and other industries up to 50 people. The number of employees is an important criterion for classifying small businesses in Japan. There it should be less than 1,000 people in mining, less than 300 people for all other industries, transport, communications and construction, less than 100 people in wholesale and less than 50 people in retail and services.

The support of individual business areas makes the government to go to the adjustment of previously entered rules. So in 1966, the American administration of small business referred to the category of small enterprises rather large company "American motors". This was done in order to give the company the opportunity to bid for government contracts, despite the fact that "American motros" was considered the 63rd largest manufacturer, had 32 thousand employees and sales revenue of \$ 991 million. The small business Administration justified its decision by saying that the company did not dominate the industry and its position and support could play a key role in ensuring the sustainability of the national automotive industry [12].

Similar measures were implemented at the time by the Chinese government, when tax incentives for small businesses were introduced in 2012. Thus, since August 1, 2013 the country has frozen the value added tax and turnover tax for small businesses, whose monthly sales volume does not exceed 20 thousand yuan (about 3.3 thousand dollars). USA. )

Thus, we can state the experience of positive influence of the state on the development of entrepreneurship, embodied in various forms of government support. But here, too, the issue of the thematic profile of such support and the areas where the points of disagreement between the parties are concentrated becomes extremely relevant.

One of the least investigated problems of assessing the current state of business-government interaction is its actualization of the media. The role of the media in the development of interaction between business and government is relevant due to the fact that the mass media form the image of this interaction in the eyes of the public, that directly affects public policy in the field of regulation of the business. 


\section{EMPIRICAL EVALUATION OF THE RESULTS OF INTERACTION BETWEEN GOVERNMENT AND BUSINESS IN THE OMSK REGION}

In order to identify the thematic blocks of contact between the positions of the government and the business community at the regional level in August 2019, the author conducted a content analysis of the media covering this issue. The applied method allowed to identify the leading topics that make up the subject of the relationship between government and business. The study used latent coding aimed at revealing the hidden, implicit meanings of the text content [13, p. 123]. The usefulness of this method of coding is manifested in the fact that, as a rule, many topics are scattered across different types of messages and do not have a strict identifier. When prioritizing a topic, consideration was given not only to the frequency of the topic and the nature of the message (analytical article, interview, report or note), but also to the time dispersion of the topic, which confirmed the persistence of interest in the topic over a long period.

In the media, this issue becomes not only the subject of public discussion, but also acquires a primary expert assessment. Print media formulate the problem, correlating it with the prevailing socio-economic and political context, embedding it in the existing institutional structure of society. The positions of the authorities and business communities are displayed on the pages of the print media, which are usually represented in the courtrooms, at meetings of the legislative and Executive authorities, in public speeches of their representatives.

The subject of the author's research was the allocation of basic strategies of the government and business communities, made on the basis of the analysis of the stories presented on the pages of the popular in Omsk printed publication "Commercial news", specializing in coverage of the problems of business development in the region, and having a fairly wide popularity among readers. The stories that get on the pages of the weekly newspaper cover the most interesting and illustrative examples of the collision of positions of authorities and entrepreneurs, which makes it possible to classify them and better understand the values of the conflicting parties. Weekly newspaper "Commercial news" is the leading business publication of the Omsk region, which is widely popular among entrepreneurs in the region.

The selection of the Omsk weekly newspaper meets the necessary requirements for the typicality of the edition being taken. The weekly newspaper specializes in coverage of issues most sensitive to public perception. In Omsk, as in most Russian cities, the share of people employed in the business sector is at least $40 \%$ of the working population. And therefore, the media is aimed at covering topics that are most relevant for this category of employees.

Empirical evaluation of the results of interaction between government and business can be performed in the context of the functions implemented within this interaction, the value of which should be determined by the degree of actualization of the relevant topic on the pages of the leading business publication of the region. This assessment can be done in the context of the 3D model, which allows us to consider the practice of interaction between business and government in the aggregate of all possible functions. The axis of development is associated with the expectations of business to receive state support for projects and organizations performing socially-oriented work, as well as with the proposal of measures for the competitive allocation of budget resources for the execution of tasks demanded by public authorities.. The development regime is confirmed in the framework of this study by the number of publications that consider various forms of business support or participation of business communities in the placement of state and municipal orders. The support and stimulation functions that ensure the development reflect the ability and readiness of the authorities to offer promising forms of business development, aiming at expanding the scope of its activities. The main objectives of the government in relation to the development of the corporate sector are:

- reduction of innovation costs for private companies;

- redistribution of budget resources in order to stimulate socially significant projects [14]. 
The mode of operation is predicated on the need to regulate the current socio-economic relations in the business environment associated with the entry of new players into this environment or the observance by all participants of the relations of the established rules. In this study, the mode of operation is identified by the number and direction of publications on disputes between business communities, business communities and authorities, the formation of conditions for business communities to conduct their production activities. The main areas of operation are the rental and property relations, litigation, taxes, administrative barriers, etc. Included in the axis of operation of the arbitration function provides assurance of the company from illegitimate claims or arbitrary action on other individuals and entities, determines the procedure of the introduction legal actions and settlement of disputes in the current mode. Thanks to the regulatory function, the authorities carry out law enforcement in the implementation of decisions, undertake operational activities to enter the territorial markets of new players and cut off those who infringe on established rules.

The mode of institutional sustainability is aimed at the formation and support of basic principles and legislative provisions that define the rules of business, as well as the rules of participation of state and municipal authorities in the regulation of current socio-economic and political processes. The control function underlying this mode is manifested in the presence of a balanced regulatory system that ensures the adjustment of the actions of counterparties in achieving their goals in accordance with the established norms. The actual problems of interaction within this function are the issues of redundancy of control, its inefficiency. Closely associated to the control function, the sanctions function is performed by specially authorized services designed to observe the rights of citizens to a safe and comfortable accommodation . However, the effectiveness and expediency of many sanctions is the subject of serious public debate due to their isolation from the alleged harm, arbitrariness of the security services initiating them, biased courts in disputes between public and private organizations.

Institutional stability is the most important condition for the existence of society, and the formation of the institutional environment is one of the most popular areas of state participation in the development of the corporate sector. D. North wrote that "the institutional environment determines the set of capabilities that certain conditions make it more profitable (economically) redistributive activity, and in other productive activities" [15, p.17]. The institutional environment helps to reduce transaction costs of the company, to overcome opportunistic behavior of business partners.

In this study, the mode of institutional sustainability is determined through the actualization of issues of administrative pressure or bureaucratic impediments, excessive regulation or the impact on business behavior of judicial precedents. In contrast to the mode of operation, we are not talking about direct ways of influence of administration on the activities of enterprises, but about a system that supports such influence, which has both positive and negative consequences for business. If the mode of operation involves the resolution of issues in the current order, in the mode of institutional stability the rules and regulations are systemic, objective in nature, and the authorities and the business community can only adapt to these rules.

Coverage of the problems of interaction between government and business in the print media is embodied in the form of: small notes, interviews with managers, analytical articles (research), reports (from the courtroom, forums and meetings). Analytical articles provide a discussion of the topic with a focused analysis of the problem. As a rule, these articles precede the issue, serve as an expression of its main theme. The analytical article reveals the content of the actualized problem, the list of parties involved in its actualization, conclusions and an invitation to discussion. Reports are information summaries from current events (court sessions, conferences, government meetings, etc.). The reports highlight the essence of the problem situation, the participants and initiators of the discussions. The reports do not provide conclusions and are intended mainly to draw attention to the problem. Notes are summaries of issues that are addressed primarily in the context of other issues. Notes do not disclose the content of the problem and only inform about the events that accompany the processes that cause these problems. And finally, the interview is a 
way of presenting the positions of a specialist, a Manager, in the process of which the actual topics, problem situations and the attitude of the interviewee are highlighted. Several actual topics may stand out in an interview, however, their coverage is subjectively colored and detailed.

Coverage of the topic in the print media can be carried out in physical and verbal contexts. The allocation of these aspects is actualized in the framework of the event analysis, which receives special additional content through coverage in the print media [16,17]. The physical context is expressed in the representation of the problem through the real interaction of counterparties, expressed in public actions, competitions, discussions, the use of expert and legal expertise, etc. Verbal context does not imply a real interaction between the parties and is primarily a form of understanding, understanding of the problem, more information about participants, etc. the Physical context is embodied in such forms of interaction as actively discouraged.and complicity. And verbal - in expectant observation and cognitive interest.

Actively discouraged.is a stable and reasoned position of one of the parties aimed at blocking the actions of the counterparty and protecting its interests. Such position in interaction of the government and business is taken by the business which is carrying out the activity by the rules established by its counterparty. Such opposition in the relevant institutional structure is carried out by business by applying to judicial and supervisory bodies. Complicity is seen here as a positive aspect of physical interaction that allows one of the parties - business - to benefit from contacts with state (municipal) bodies, improve the business environment, reduce the financial burden or obtain new sources of financing.. The most characteristic form of participation can be, for example: participation of a business structure in public procurement, grants, organization of various forms of equal and mutually beneficial cooperation, etc. The expectant observation does not involve detailed coverage of the event, making assessments and judgments. The object of expectant observation is an unfamiliar sphere of business or regulatory innovations. The interest here is not people, but mechanisms, the use of which has a high degree of uncertainty. Cognitive interest is focused on more topical issues that have a wide awareness among the participants of the interaction. Therefore, the interest is details of heightened engagement, role of specific individuals in their initiation and participation, the impact of these events on social processes, etc. Thus, in contrast to expectant observation cognitive interest means the reflection of the reader to the materials, the emphasis on identifying underlying mechanisms of events. In the center of expectant observation lies the plot, the story, the narrative.

In carrying out the content analysis of the materials of the business newspaper of the Omsk region "Commercial news", taken for the period from 2018 to August 2019, priority problems of interaction between business and government were identified, which received the most coverage on the pages of the weekly. In total, 79 issues of the weekly Newspaper were analyzed (49 issues in 2018 and 30 issues in 2019). The prioritization was assessed by calculating the frequency of the topic being mentioned in the print edition and by taking into account the nature of the communication, the highest being the analytical article and the lowest - the note. The most pressing issues highlighted on the pages of the weekly were the following topics:

1. The level of rent and redemption prices for urban real estate;

2. Abundance of control checks and coordination procedures in supervisory bodies;

3. The inability of business structures to resist illegal actions of law security services that limit business opportunities;

4. Corruption in government.

The allocation of thematic blocks of the problems of interaction between business and government, covered in the media, allows us to diagnose the contradictions between the parties that are specific to modern Russia. The resolution of these contradictions can be carried out in the form of model agreements fixing the area of intersection of the interests of the government and the business community. 
The publication topics identified in the study can be divided into three groups corresponding to the axes of interaction identified above.

The mode operation displays the current activities of the authorities and business communities in the framework of the fulfillment of their obligations without the need to bring this interaction to a higher level. The publication topics included in this group actualize the ability of the authorities to create conditions for the creation and support of existing business communities, resolve or overshadow the emerging differences, make decisions to correct crisis situations. The position of the authorities in relation to business in this case is neutral, aimed at forming long-term rules and following them. The mode operation (functions-arbitration, regulation) is represented by such topics as:

Setting the rent rate for land, the determining of purchase price of real estate;

The entry of the regional debris operator into the regional market;

Declaring bankruptcy;

Discussions on the regulation of street trade (holding a tender for the construction of shopping malls);

Fulfillment of obligations by foreign companies (China national chemical engineering company); Problems of regulation of cemetery business.

In contrast to the operation mode, the Development mode assumes positive expectations of business from the government, being focused on publication topics that reflect the active actions of the government to increase the entrepreneurial activity of citizens, the promotion of some enterprises or industries on qualitative new level .

The Development mode (functions - assistance, support) " is represented by the following topics : Introduction of concession mechanism in the construction of social facilities;

Support of some enterprises of public importance (Omskelektro, "Heat company, etc.);

Development of self-employment;

The provision of incentives for small businesses;

Development of the entrepreneurship support Fund.

A special place in the model of interaction between business and government is given to the mode"Institutional stability", in which the most debated problems in the social discourse are concentrated and where the authorities have a limiting influence on their counterpart. Here the government manifests itself as the Supreme regulator, establishing patterns of sanctioned and unauthorized behavior of regulated entities, setting current precedents and demonstrating the reaction of the authorities to the existing rules.

The mode "Institutional sustainability (control functions, sanctions)" consists of the following topics:

Theft from the accounts SRO (Self-regulating organizations) "First Guild of builders" Stinko (insurance of civil liability of participants of participatory construction, "the case of Matzilevich»); Civil liability of participants in participatory construction;

Influence of security services on the state of business in the region

Fiscal discipline.

The themes covered in this Newspaper were divided between 4 message types as follows (table 1): 
Table 1. The division of thematic blocks by message types

\begin{tabular}{|c|c|c|c|c|}
\hline Thematic block & $\begin{array}{c}\text { Message } \\
\text { types }\end{array}$ & & & \\
\hline & $\begin{array}{l}\text { Analytical } \\
\text { articles }\end{array}$ & Reports & Interviews & $\begin{array}{l}\text { Small } \\
\text { notes }\end{array}$ \\
\hline \multicolumn{5}{|l|}{ Operation } \\
\hline $\begin{array}{l}\text { Setting the rent rate for land, the determining } \\
\text { of purchase price of real estate; }\end{array}$ & 8 & 8 & 12 & 14 \\
\hline $\begin{array}{l}\text { The entry of the regional debris operator into } \\
\text { the regional market; }\end{array}$ & 5 & 4 & 14 & 14 \\
\hline Declaring bankruptcy; & 6 & 6 & 12 & 16 \\
\hline $\begin{array}{l}\text { Discussions on the regulation of street trade } \\
\text { (holding a tender for the construction of } \\
\text { shopping malls); }\end{array}$ & 4 & 4 & 9 & 8 \\
\hline $\begin{array}{l}\text { Fulfillment of obligations by foreign } \\
\text { companies (China national chemical } \\
\text { engineering company); }\end{array}$ & 2 & 4 & 4 & 6 \\
\hline Problems of regulation of cemetery business. & 2 & 3 & 4 & 4 \\
\hline \multicolumn{5}{|l|}{ Development } \\
\hline $\begin{array}{l}\text { Introduction of concession mechanism in the } \\
\text { construction of social facilities; }\end{array}$ & 3 & 5 & 6 & 6 \\
\hline $\begin{array}{l}\text { Support of some enterprises of public } \\
\text { importance (Omskelektro, "Heat company, } \\
\text { etc.); }\end{array}$ & 2 & 3 & 4 & 4 \\
\hline Development of self-employment; & 1 & 3 & 3 & 3 \\
\hline $\begin{array}{l}\text { The provision of incentives for small } \\
\text { businesses; }\end{array}$ & 1 & 1 & 2 & 2 \\
\hline $\begin{array}{l}\text { Development of the entrepreneurship support } \\
\text { Fund. }\end{array}$ & 2 & 2 & 3 & 3 \\
\hline \multicolumn{5}{|l|}{ Institutional sustainability } \\
\hline $\begin{array}{l}\text { Theft from the accounts SRO (Self-regulating } \\
\text { organizations) "First Guild of builders" Stinko } \\
\text { (insurance of civil liability of participants } \\
\text { of participatory construction, "the case of } \\
\text { Matzilevich»); }\end{array}$ & 6 & 10 & 8 & 6 \\
\hline $\begin{array}{l}\text { Civil liability of participants in participatory } \\
\text { construction; }\end{array}$ & 2 & 4 & 4 & 3 \\
\hline $\begin{array}{l}\text { Influence of security services on the state of } \\
\text { business in the region }\end{array}$ & 3 & 5 & 5 & 7 \\
\hline Fiscal discipline. & 3 & 4 & 8 & 6 \\
\hline
\end{tabular}

Analysis of the intensity of coverage of the above topics, carried out by calculating these topics by types of publications, showed that the greatest interest in the pages of the newspaper caused the mode of operation. The dominant role of the mode of operation in the interaction of business and government is determined mainly by the fact that the results of the study revealed the instability of the institutional structure and the unwillingness of government and business to change anything 
in it. The main efforts to improve this interaction were made mainly within competence of the regional authorities, that need of tax revenues from business structures. Therefore, the first place of public discussions in the media are the issues of economic feasibility of rental rates for state and municipal property or methods of regulation of some industry markets (primarily trade).

The extremely low degree of actualization is demonstrated by the axis of development, which has not received decent coverage on the pages of the weekly. The low capacity of the regional authorities to support entrepreneurship significantly contain this vector of interaction. Typical in this regard is the example of the use of the concession mechanism in the construction of the cinema "Pervomaisky", the legal controversies on the opening of which scared off the business from turning to this mechanism. The analysis of publications revealed a significant deficit in obtaining ideas about promising forms of doing business and ways to stimulate the corporate sector.

The vector of institutional stability can be measured by the number of topical stories about the inability (unwillingness) of the current legislation and existing social institutions to regulate various spheres of entrepreneurial activity. The weakness of the institutional stability factor is manifested in the lack of effective measures that can be taken by the local authorities in the framework of the protection of local enterprises due to contradictions in Federal legislation, the influence of large holding structures, the inefficiency of the judicial system, etc. That institutional instability made possible the updating of the "case of Matzilevich", the coverage which the media was given a large number of publications. The peculiarity of this case was the lack of a number of necessary regulators that would limit the possibility of extracting the benefits of unscrupulous entrepreneurs from the accumulation of funds for insurance needs.

\section{CONCLUSION}

Thus, our analysis allowed us to reconstruct the structure of interaction between government and business through its actualization in the printed business weekly. This technique made it possible to understand the negative trends in the development of the business environment recorded by statistical documents and to compliment the reconstruction with verbal ways of updating information about the forms of such interaction. Print media currently perform the most important function of translating the attitudes and expectations of society, and the stories placed on their pages, act as a picture of the real problems faced by the subjects in their daily lives. The model of interaction between business and government developed in the framework of the study provides an opportunity to structure the problems of interaction between the leading contractors of social relations, as well as to regularly assess changes in public expectations and the relevance of problematic issues.

3-d model has a universal character for the analysis of the interaction between business and government and can be used as the instrument of diagnostics of the state of interaction between business and government. The definition of numerical values for each of the 3 axes of the presented model, that attests to the actualization of some form of thematic block, gives the opportunity to the government to adjust the policy in the field of business facilitation, to find adequate measures for increasing of quality of such interaction 


\section{REFERENCES}

[1] Bogachev M. I. (2011) Splicing as the oldest mechanism of dialogue between government and business in Russia. Business. Society Power. No. 6, 74-83. (In Russian)

[2] Galitsky E., Levin, M. (2007). Corruption in the relationship between business and government (the case of empirical analysis). Problems of Economics.. No. 1,17-32 (In Russian)

[3] Oleynik A. (2011). Political Economy of power: approaches to the analysis of relations between the state and business in Russia. Questions of economy. No. 5, 19-33 (In Russian)

[4] Barysheva G.A., Nekhoroshev Yu.S. (2005) Government and business: legal and criminal mechanisms of interconnection. News of TPU.. No. 6, .203-206 (In Russian)

[5] Butova T.V.,. Erkhov M.V. (2007) Government and business in modern society, Moskow, Maroseyka, (In Russian)

[6] Shevchenko E.A. (2017) The role of public-private partnership in the system of interaction between business and government. Economics and Management: Problems and Solutions.. No 3 (3), 13-17 (In Russian)

[7]Alieva T. (2017) Model of the interaction of Government and business in the field of environmental management in the Russian Arctic. Problems of theory and practice of management.. No 1, 19-25 (In Russian)

[8] Government and Business in Russia: Interaction in a Crisis: Monograph / Ed. A.N.Shokhin. [2016], Moskow, SU-HSE (In Russian)

[9] Government and business: communication resources (2011). Collection of scientific articles. Series "Communicative research", Issue 5, Moskow, HSE (In Russian)

[10] Jawahar I. M., McLaughlin G. L. (2002). Towards a descriptive stakeholder theory: An organizational life cycle approach. Academy of Management Review 26 (3): 397-414.

[11] Business mortality: in 2018 in Russia closed twice as many companies than opened: June 6, 2019, from https://finexpertiza.ru/press-service/researches/2019/smertnost-biznesa-za-2018/ (In Russian)

[12] Little and slowly. (2015). Rossiyskaya Gazeta, from https://rg.ru/2015/04/14/dola.html]. (In Russian)

[13] Newman L. (1998) Nonreactive research and available data / / Sociological researches. No. 6, 119-129 (In Russian)

[14] Sablin K. S. (2012) The role of the institutional environment in the formation of development institutions. Journal of institutional studies (journal of institutional studies), Volume 4, No 2. 2012, 32-42 (In Russian)

[15] North, D.(1998). Five Propositions about Institutional Change // Explaining Social Institutions / Ed. by J. Knight and I. Sened. Michigan: The University of Michigan Press, 15-27

[16] Mannheim George.B., Rich R. K. (1997) Political Science: research methods: TRANS. Moskow, the whole world (In Russian)

[17] Borishpolets K. P. (2005) Methods of political research: Studies. Manual for students. Higher educational. Moskow, Aspect press (In Russian)

Internet source:

[1] www.bbc.com/russian/rolling_news/2013/07/130725_rn_china_growth_boost.shtml

[2] Newspaper"Commercial news" http://kvnews.ru/ 